\title{
THE CRISIS OF THE THIRD CENTURY A.D. IN THE ROMAN EMPIRE: A MODERN MYTH?
}

By

\section{LUKAS DE BLOIS}

Until well into the seventies of the last century the third century A.D. was perceived as a period of crisis, a crisis which was already announced under the emperor Marcus Aurelius A.D. 161-180), whose reign was characterised by warfare and epidemics.

Many observers saw the third century crisis as a decisive period of transition to Medieval History. In a highly rhetorical and suggestive passage in his Birth of the Western Economy, Robert Latouche describes the second and third quarters of the third century A.D. as ".. a sinister age, the least known of the whole history of Rome.." and he tells us: "After the reign of the Severi we seem to plunge into a long tunnel, to emerge only at the beginning of the Late Empire under Diocletian, and when we step out again into daylight unfamiliar country lies all about us".

In later decades the third century crisis was seen as a complex historical process, brought about by the interaction of many different factors. Geza Alföldy summarises the various aspects of the crisis that dominated the history of the Roman empire from 249 to 284 in nine points: the switching from the rule of an emperor to that of a military despot, the general instability, the growing power of the armies, the increasing influence of the military provinces such as those along the Danube, social shifts, economic problems, the decrease in and unequal distribution of the population, a religious and moral crisis and invasions of foreign peoples in practically all border regions and even beyond, into the heartlands of the empire. ${ }^{2} \mathrm{He}$ could have added the collapse of the existing monetary system, problems about the legitimacy and the ideological basis of imperial power, the decay of small and medium-size towns and the decay of local euergesia and public services.

One of Alföldy's factors, the invasions, were emphasised by Ramsay MacMullen. On the first two pages of his Roman Government's Response to Crisis MacMullen says:

${ }^{1}$ R. Latouche, The Birth of the Western Economy (London 1961), 6.

${ }^{2}$ G. Alfoldy, 'The Crisis of the Third Century as Seen by Contemporaries', Greek, Roman, and Buzantine Studies 15 (1974), 98-103 (= Idem, Die Krise des römischen Reiches. Geschichte, Geschichtsschreibung und Geschichtsbetrachtung. Ausgewählte Beiträge [Stuttgart 1989], 328-333). 
"If the half century after 235 is approached in the manner of its contemporary historians and through the most salient and accessible facts, its chief features can be arranged in a comprehensible line. First foreign wars. Alexander Severus' unsuccessful handling of these prepared his death. These too prevented his successors from gaining a firm seat in the throne they scrambled up to. Such recurrent failure to restore political stability generated civil strife as much as it attracted invasions. Augusti had therefore to arm themselves on two fronts. They needed money in unprecedented quantities, and laws and men somehow to produce it. Armies, bureaucracies, and taxes all grew suddenly, simultaneously. At the same time, the economy in the areas closest to the scenes of wars became less able to meet the demands placed on it, because it was pillaged and fought over; and that combined mint master and paymaster, the desperate emperor of whatever reign, accordingly stretched his supplies of silver over a larger and larger bulk of more and worse coinage. Inflation set in, to a degree unprecedented. With this (as with a super-added plague, divinely appropriate to cap the whole structure of catastrophe), even folk inside the least disturbed areas like Campania or Southern Gaul had to reckon, and adapt their lives to it". ${ }^{3}$

In recent years this gloomy picture has become a matter of doubt. KlausPeter Johne and his fellow authors believe that the third century crisis really existed, but was not an all- encompassing cataclysm in all regions of the empire alike. They maintain that agriculture and urbanism came into trouble in the Rhinelands and the Middle Danube region, but not in the Balkans, let alone in regions that were not affected by warfare. They observe that at the end of the third century still many cities existed, a good deal of which came into a new phase of relative prosperity, although curiales lost ground to military men, bureaucrats, and rich landowners who belonged to the top layers in society, but owned land within the borders of communities. The curiales did not have enough power to have them pay their dues. Nonetheless the senatorial order was one of the great losers of third century

\footnotetext{
${ }^{3}$ R. MacMullen, Roman Government's Response to Crisis A.D. 235-284 (New Haven/London 1976), $1 \mathrm{f}$.
} 
changes. Senators were ousted from the armies and from provincial government, which was taken over by military men from the ordo equester. ${ }^{4}$

Other scholars ascribe the myth of the third century crisis to biased stories made up by historiographers like Cassius Dio and Herodian, who were anxious at the prospect of losing their class privileges to the rising power of the military, or by contemporary Christian authors, who thought that the age of the Prince of Darkness, which should precede the Second Coming of the Lord, was at hand. ${ }^{5}$ One may ask oneself, however, how these authors could have made up stories that were simply not true. Their readers knew third century circumstances and would have rejected their works if these authors had done so.

Some specialists of third century history accentuate the manifold continuity that characterised this Roman age. And indeed continuity reigned in military strategy and tactics, in the administration of justice, in public religion, and in the presentation of imperial power, i.e. in the continuous practicability of traditional imperial coin legends and images and of paradigmata like Augustus, Trajan and Marcus Aurelius. Furthermore until 260 emperors tenaciously tried to maintain Antonine traditions in their appointment policies, particularly in the appointment of senators to posts to which they were traditionally entitled. ${ }^{6}$ In the East Greek paideia maintained

${ }^{4}$ See K.-P. Johne, ed., Gesellschaft und Wirtschaft des Römischen Reiches im 3. Jahrhundert. Studien zu ausgewählten Problemen von Gerda von Bülow, Hagen Fischer, Klaus-Peter Johne, Detlef Rössler und Volker Weber (Berlin 1993), 7-317; J.- M. Carrié \& A. Rousselle, L' empire romain en mutation des Sévères à Constantin, 192-337 (Paris 1999), 9-14.

${ }^{5}$ See for example Cyprian, Ad Demetrianum 3-10. See Alfoldy 1989, op.cit. (n.2), 295-318; D.S. Potter, Prophecy and History in the Crisis of the Roman Empire. A Historical Commentary on the Thirteenth Sibylline Oracle (Oxford 1990), 95-103; K. Strobel, Das Imperium Romanum im ' 3. Jahrhundert'. Modell einer historischen Krise? (Stuttgart 1993), 49-138.

${ }^{6}$ On continuity in many aspects of Roman politics and administration,until A.D. 260, and in some respects even after, see $M$. Christol, $L$ ' empire romain du IIle siècle. Histoire politique 192-325 après J.-C. (Paris 1997), 11-232. See P.M.M. Leunissen, Konsuln und Konsulare in der Zeit von Commodus bis Severus Alexander (180-235 n.Chr.) (Amsterdam 1989), 102-105 and M. Christol, Essai sur l' évolution des carrières sénatoriales dans la deuxième moitié du IIIe siècle ap. J.-C. (Paris 1986), $17-$ 34 (continuity in appointment policies); A.M. Honoré, 'Imperial Rescripts A.D. 193-305. Authorship and Authenticity', Journal of Roman Studies 69 (1979), 62 (continuity in the style of imperial rescripts); R.A.G. Carson, Coins of the Roman Empire (London/ New York 1990), 53-85 (on continuous imperial monetary policies); R. Lane Fox, Pagans and Christians in the Mediterranean World from the Second Century A.D. to the Conversion of Constantine (London 1986), $80 \mathrm{ff}$. and Alföldy 1989, op.cit. (n.2), 349-387, esp. 364 ff. (on continuous religious phenomena). On continuity in imperial titulature see also ILS I 413-521, a fairly representative sample of imperial titulature in those times, and M. Peachin, Roman Imperial Titulature and Chronology A.D. 235-284 (Amsterdam 1990), passim. 
the traditions of the Second Sophistic. ${ }^{7}$ In all parts of the empire Greek and Roman upper classes kept sharing the Greek classical past as a common frame of reference. ${ }^{8}$

Continuity also dominated the social and economic structures of many regions, which were not directly hit by invasions or internal strife. In 1999 Witschel demonstrated that until the third quarter of the third century regions like Italy, Gaul, Britain, Spain, and Northern Africa maintained their traditional infrastructures, their density of population and their prosperity. ${ }^{9}$ To prove his thesis Witschel leans heavily on archaeological evidence. Material remains do not tell us, however, anything about indebtedness and diminishing carrying - capacities that threatened the continuity of euergesia, social tensions which undermined local patriotism, decreasing resources in a period of apparent continuous prosperity, and the relative weight of taxation and requisition. About these issues there is not enough evidence to come to any suppositions, let alone conclusions. Material remains tell us that people went on living in an area, at more or less the same levels of material culture, and in more or less the same built environment. They do not even tell us anything about demographic movements. Even Witschel, who tries to explain away the third century crisis on almost every page of his book, has to admit that there is archaeological evidence that, in times of prolonged warfare, like the periods $165-180$ and 250-284, people started to leave their homesteads in war-ridden areas like the Danube provinces and the Agri Decumates. ${ }^{10}$

The continuities I mentioned can have existed in societies that were already under heavy and increasing tensions, which did not yet destroy traditional culture and life style. There are indeed some signs that this may have happened. A problem that runs through Greek literary works of the first half of the third century A.D. is the exceedingly heavy burden of taxation. In a recurring commonplace bad emperors are accused of feasting on money

\footnotetext{
${ }^{7}$ See Th. Schmitz, Bildung und Macht. Zur sozialen und politischen Funktion der zweiten Sophistik in der griechischen Welt der Kaiserzeit (München 1997), 33.

${ }^{8}$ To give only one example: in A.D. 242 Gordian III started his military campaign against the Persians by opening the gate of Ianus and by instituting new games in Rome for Athena Promachos, the goddess who had helped the Greeks against the Persian king Xerxes, many ages before. See Eutropius, Breviarium 9.2.2; Zosimus 1.18.2. See L. Robert, 'Deux concours grecques à Rome: Antonia Pythia sous Elagabal et concours d' Athena Promachos depuis Gordien III', in Idem, Opera Minora Selecta V (Amsterdam 1989), 647-668 (= Comptes Rendues de l' Académie des Inscriptions 1970, 6-27); Christol 1997, op.cit. (n.6), 96.

${ }^{9}$ Chr. Witschel, Krise-Rezession-Stagnation? Der Westen des Römischen Reiches im 3. Jahrhundert n.Chr. (Frankfurt a.M. 1999).

${ }^{10}$ Witschel 1999, op.cit. (n.9), 178 ff. and esp. 207 ff.
} 
wrung from the poor and of robbing the rich to satisfy the soldiers. ${ }^{11}$ In a mutilated papyrus text which contains a copy of an imperial letter which Oliver convincingly ascribes to the emperor Severus Alexander, we read that the emperor, who has sent this letter, will not compel cities to contribute more golden crowns or sums due in place of them, than they are able to give. He would have liked to offer, he says, a more conspicuous proof of his magnanimity and to remit arrears, but the poverty of the government prevents him to do so. He has, however, not failed to observe, that the amounts he has received are all that the cities can afford to pay. So he remits the last contribution, due on the occasion of his accession to the imperial throne. ${ }^{12}$ In his Opera Minora Selecta V (Amsterdam 1989) Louis Robert mentions a priest from Asia Minor who could no longer make ends meet and wished to escape the obligations of euergesia. He demonstrates that such problems were a common feature of those times, the third century A.D. ${ }^{13}$ Papyrus texts from Egypt show us that in that province financial problems rose, although they did not lead to structural changes in culture and society. Petitions from villages like Skaptopare, Aragoë and Takina show that villagers brought forward their complaints. Apparently their communities were on the verge of collapse. ${ }^{14}$ Herodian (7.3) tells us that harsh tax raising in the days of Maximinus Thrax raised un unprecedented uproar and ultimately led to the rebellions of 238. People could take no more. A bad sign is the growing frequency of curatelae in career inscriptions of senators. Curatores had to see to it that local magistrates did not spend their money on prestigious projects and consequently ran into debts, but set aside supplies

\footnotetext{
${ }^{11}$ See Cassius Dio 52. 28-29; 72.3 .3 f.; 73.16.2 f.; 75.8.4 f.; 77.9 and 13-16; 78.9-14; Herodian 3.8 f.; 6.1.8 f.; 7.3.1 ff.; Philostratus, Vita Apollonii 5.36; Ps.-Aelius Aristides, Eis basilea 16 and $30 \mathrm{ff}$; P. Lond. inv. 2565; P. Fay. 20. See Christol 1997, op.cit. (n.6), 48 f.; 85; 103; P. Cosme, L'état romain entre éclatement et continuité (Paris 1998), 86-95.

${ }^{12}$ See P. Fay. $20=$ A.S. Hunt \& C.C. Edgar, Select Papyri II (London/ Cambridge, Mass. 1956), nr. 216. See J.H. Oliver, 'On the Edict of Severus Alexander', American Journal of Philology 99 (1978), 474-485.

${ }^{13}$ L. Robert, 'Trois oracles de la théosophie et un prophète d' Apollon', in Opera Minora Selecta V (Amsterdam 1989), 584-604 (= Comptes Rendues de l' Académie des Inscriptions 1968, 568-599), esp. 596-602.

${ }^{14}$ See L. Robert, 'Sur un papyrus de Bruxelles', Revue de Philologie 17 (1943), 115 ff.; S. Mitchell, 'Requisitioned Transport in the Roman Empire. A New Inscription from Pisidia', Journal of Roman Studies 66 (1976), 114 f.; P. Herrmann, Hilferufe aus den römischen Provinzen. Ein Aspekt der Krise des römischen Reiches im 3. Jh. n.Chr. (Hamburg/Gottingen 1990), nrs. 4, 6 and 8 (4 = CIL suppl. 12336 = IGR I 674 = Sylloge 888, from Skaptopare; 6 = OGIS $519=$ IGR IV 598, from Aragoe); F. Millar, The Emperor in the Roman World (London 1992, 2nd ed.), 646 (= SEG 37 [1987], 1186).
} 
and money, for example for passing armies. ${ }^{15}$ The surprising frequency of curatores in Italy for example may have something to do with devastations in the direct hinterlands of the Danube armies, which made Italy into one of their main sources of supplies. A passage in Herodian's work is very interesting in this respect. In 8.2.3 he tells us that many goods found their way to the Danubian provinces through Aquileia.

So, was there a crisis after all? Or is it a modern myth, made up by authors who liked to place the beginning of the decline and fall of the empire into the third century? Political crises, which manifested themselves in civil wars and usurpations, destabilised the Roman Empire in A.D. 192-197, 217-218, 238, 249,253 , and above all in A.D. $258-274 .{ }^{16}$ But did existing problems grow into a deeper, more complex, many-sided, and more serious crisis, which could result in changes in life styles and social structures, and could threaten the continuity of the Roman system?

First, what harm may have been wrought by military misbehaviour, which ranks first in gloomy passages written by Cassius Dio and Herodian, and has a special place in most modern explanations of third century problems? In all his eighty books Cassius Dio is virtually obsessed with the risks of military misconduct. Dio regarded armies as the main source of power and he branded soldiers as a naturally rebellious species that is to be classed with robbers and that is difficult to control. And yet controlled it must be, for otherwise a legitimate monarchy or a republican government will degenerate into a military tyranny and the whole social structure will be turned upside down. In his view there is a great risk of this taking place when the government loses its dignity, when the community is weakened by discord or when a despotic or uneducated ruler regards the armies as his personal retinue and spoils them, at the expense of the rest of the population. ${ }^{17}$ Dio probably wrote his work in those decades, between 211

\footnotetext{
${ }^{15}$ See W. Eck, Die staatliche Organisation Italiens in der Hohen Kaiserzeit (Munich 1979), 190-226; G.P. Burton, 'The curator rei publicae: Towards a Reappraisal', Chiron 9 (1979), 465-487, esp. 482 f. A prosopography of curatores rei publicae has been published by F. Jacques, Les curateurs des cités dans l'occident romain (Paris 1983). On the basis of Burton's investigations one may conclude that in Asia Minor regional aristocrats, in local status comparable with status set senators in Italy, were selected to be city curators. Like those senators they had the ascendancy to impress local notables. They had to see to it that local councils set aside money and supplies for the armies. On local finance see also L. Migeotte, L'emprunt public dans les cités grecques (Paris/ Québec 1984), $359 \mathrm{ff}$.

${ }^{16}$ See Christol 1997, op.cit. (n.6), 11-22; 35 f.; 45-59; 85-89; 119-165.

${ }^{17}$ On Cassius Dio's view of the soldiery see L. de Blois, 'Volk und Soldaten bei Cassius Dio', in H. Temporini \& W. Haase, eds., Aufstieg und Niedergang der Römischen Welt II 34,3 (Berlin/ New York 1997), 2650-2676; Idem, Emperor and Empire in the Works of Greek-speaking Authors of the Third
} 
and 235. Herodian, regarded the greed and lack of discipline of the soldiers as the root of much evil and in his opinion these vices were growing stronger. In a passage on the murder of the emperor Pertinax in 193 and the 'sale' of the emperorship to Didius Iulianus in the camp of the praetorian guard he writes: "This was the first time that the soldiers' characters gradually began to be corrupted. They learned to have an evil and insatiable lust for money and to ignore any feeling of respect for their emperors. The fact that there was nobody to take revenge on the perpetrators of this savage murder of an emperor, and nobody to prevent the shameful auction and sale of the empire, was a prime cause in the development of a shameful state of indiscipline that had permanent consequences for the future. The everincreasing avarice of the soldiers and their contempt for authority had developed to the extent of murder" (Herodian 2.6.14). According to Geza Alföldy Herodian died after A.D. 250. So he may have seen the first phase of third century troubles. ${ }^{18}$

From 230 and indeed from 249 dangerous wars arose in the East and North. Until 253 the most dangerous wars did not yet coincide, but from 253 simultaneous wars at several frontiers became a common feature of Roman history, which forced the emperors to move frequently vexillationes from the legions, auxiliary units and detachments from the fleets from one border region to another, to concentrate armies which would be big enough to beat the enemies. ${ }^{19}$ What about the consequences? There are no elaborate, detailed third century reports about such military movements, but in the Histories of Tacitus there is a story, which may be used as an eye-opener, a parallel which can give us a clue. In Histories 1.63-66 Tacitus tells us how the army of Valens, one of the commanders of Vitellius in the civil wars of A.D. 69, travelled from the Rhine frontier through Gaul to Italy. Valens' troops had no trouble with the Treveri, whom they knew as trustworthy allies. But without any obvious reason they murdered 4000 people - the

Century A.D.', in H. Temporini \& W. Haase, eds., Aufstieg und Niedergang der Römischen Welt II 34,4 (Berlin/ New York 1998), 3411 f.; Idem, 'The Perception of Emperor and Empire in Cassius Dio's Roman History, Ancient Society 29 (1998-1999), 275 ff.

${ }^{18}$ On Dio's life and career see De Blois 1998, op.cit. (n. 17), 3405 f. On Herodian see Alföldy 1989, op.cit. (n.2), 240 ff.; De Blois 1998, op.cit. (n.17), 3415 ff. On Herodian's work see M. Zimmermann, 'Herodians Konstruktion der Geschichte und sein Blick auf das stadtrömische Volk', in Idem, ed., Geschichtsschreibung und politischer Wandel im 3. Jh.n.Chr. (Stuttgart 1999), 119-143; Th. Hidber, 'Zeit und Erzählperspektive in Herodians Geschichtswerk', in the same volume, 145-167. Zimmermann seems to think that Herodian was a 'Stubengelehrter', though not on good grounds. See Alföldy 1989, op.cit., $240 \mathrm{ff}$.

${ }^{19}$ On the history of the tumultuous years 249-271 see Christol 1997, op.cit. (n.6), 121-158. 
number is given by Tacitus - in Divodurum. From that moment onwards city magistrates and town councils of communities through which the soldiers passed were eager to offer anything that the army of Valens needed. His soldiery sought a pretext to plunder the Aedui, one of the next tribes they met, but they could not find any. The Aedui handed over weapons and money and provided food free of charge. Lugdunum welcomed the soldiers whole-heartedly. Of course it did. In a recent article Rudolf Haensch demonstrates that many veterans of the Rhine armies retired to this place. ${ }^{20}$ The citizens of Lugdunum tried to persuade Valens and his army to punish Vienna, their fiercest competitor, but the Viennenses forestalled disaster by handing over their arms and procuring goods taken from the fortunes of rich fellow-citizens. Suddenly Valens was a very rich man. Traversing the territories of the Alllobroges and the Vocontii this general earned some more handsome profits through forced transactions with landed proprietors and local magistrates who had to procure food, goods and facilities. The other Vitellian army, commanded by Caecina, devastated the land of the Helvetians, who had risen in rebellion and were badly beaten. The conflict had started after soldiers of Caecina's army, of the twenty-first legion, had stolen the money with which an Helvetian border garrison that was paid by the Helvetians themselves should be paid (Tacitus, Historiae 1.67-69).

All this is highly rhetorical, but it gives us a clue. Passing armies demanded goods, food and facilities and could easily turn into looting mobs. So local magistrates gave them what they asked and could not resist. Local notables changed into subservient slaves of passing armies and must have lost face in the eyes of their fellow citizens. They must have lost a lot of money and supplies too. The generals of passing armies could become rich and do business on a large scale, demanding food and goods free of charge or at a low price. Complaints and petitions about military misconduct were recurring phenomena in Roman imperial history. There are examples from the reigns of Augustus, Tiberius, and Hadrian, to mention only some good rulers, who reputedly were able to discipline the soldiers. ${ }^{21}$ In a papyrus text from the days of the emperor Hadrian we read:

\footnotetext{
${ }^{20}$ R. Haensch, 'Milites legionis im Umfeld ihrer Provinz. Zur Rekrutierungspraxis, sozialen Position und zur 'Romanisierung' der Soldaten der niedergermanischen Legionen im 2. und 3. Jahrhundert', in L. de Blois, ed., Administration, Prosopography, and Appointment Policies in the Roman Empire. Proceedings of the First Workshop of the International Network Impact of Empire (Roman Empire, 27 B.C. - A.D. 406), Leiden, June 28 - July 1, 2000 (Amsterdam 2001), 84-108.

${ }^{21}$ See Suetonius, Augustus 24.2; Tacitus, Annales 1.16-30 and 31-52 (on the mutinies in the Rhine and Danube armies in A.D. 14); PSI 446 = Hunt \& Edgar 1956, op.cit. (n.12), II nr 221.
} 
"I (i.e. the praefectus Aegypti) am informed that without having a warrant many of the soldiers when travelling through the country requisition boats and animals and persons improperly, in some cases seizing them by force, in other obtaining them from the strategi through favour or obsequiousness, the result of which is that private persons are subjected to insults and abuses and the army is reproached for greed and injustice". The prefect commands never to furnish to any person without a warrant any contribution for the journey (PSI 446).

So Tacitus' report about the Vitellian armies may not be an exaggerated horror story about an isolated event.

There are just enough indications which suggest that similar things happened in the third century, especially along the great military transit routes. Under Caracalla, Gordian III and Philip the Arabian, already well before the intense military activity of the period 249-284, villagers from Takina, Skaptopare and Aragoe, places in the Balkans and Asia Minor, complained to the emperors telling them that military avarice and misbehaviour had brought them into misery and bankruptcy, which would ultimately lead to less tax returns from their regions. Looting bands of soldiers had left the highways and had visited villages which were situated relatively far from the military transit routes. ${ }^{22}$ One may surmise that places that were situated nearer to those routes had already been bled white. This kind of misbehaviour became proverbial. In the Vita Alexandri Severi in the Historia Augusta, an utopian treatise full of commonplaces which belongs to the genre of mirrors-of-princes, one of the things a good emperor has to prevent, and which Severus Alexander according to this author did prevent indeed, is precisely this roving away from highways by groups of soldiers (SHA, Alexander Severus 51.6). We should not forget that this type of wild foraging came on top of regular demands. In the same Vita Alexandri Severi the emperor is praised because he, before marching to the East against the Persians in A.D. 230, made such careful provision for the soldiers that they were furnished with supplies at each halting place and were never compelled to carry food for the usual period of 17 days, except in the enemy's country

\footnotetext{
${ }^{22}$ Herrmann 1990, op.cit. (n.14), nrs. 4, 6 and 8 (4 = CIL suppl. 12336 = IGR I $674=$ Sylloge 888, from Skaptopare; 6 = OGIS 519 = IGR IV 598, from Aragoe); Millar 1992, op.cit. (n. 14), 646 (= SEG $37,1987,1186)$.
} 
(SHA, Alexander Severus 17.1). So the inhabitants of the regions through which the army was to travel had to bring food to the halting places beforehand, either free of charge or as frumentum emptum, paid at price levels that the emperor and his commanders ordained. Exceptions confirm rules. Herodian tells us that the soldiers of Maximinus Thrax, who in A.D. 238 wished to annihilate his senatorial opponents in Italy before they could unite with the Gordians in Northern Africa, had to carry many supplies, because they marched quickly, without the usual preceding planning and distribution of supplies among mansiones and storehouses along the highway they had to take (Herodian 7.8.11).

In areas where prolonged warfare had become a recurrent phenomenon worse things happened. Again, there is no detailed contemporary third century report. And again a parallel may help us out. In his stories about the exploits of Julian in Gaul, in the middle of the fourth century A.D., Ammianus Marcellinus describes the miserable situation in border provinces which - year after year - were plundered by roving bands of Franks or Alamans, In book 17, chapter 8, of his work Ammianus tells us that in 358, one year after the great battle at Strasbourg and after several years of continuous warfare and plunder in the Northeast of Gaul, Julian preferred to wait for supplies coming in from Aquitania before starting a new campaign. Northern Gaul and the Rhineland had obviously come into dire straits and could no longer provide enough. ${ }^{23}$ Above I have ventured the hypothesis that - after periods of prolonged warfare- in a similar way Italy became the main supply base for the army of the Middle Danube in the times of Marcus Aurelius and in the middle of the third century. In repeatedly devastated regions people would start to move away. In his book on warfare and food supply in Roman republican wars Paul Erdkamp has demonstrated that short raids and limited periods of warfare did not cause mass migrations, because farmers could apply other survival strategies, like the production of rapidly growing alternative crops and borrowing from relatives, friends and patrons. Prolonged warfare, however, resulted in the destruction of stores, livestock and tools and would trigger widespread migration to safer regions. ${ }^{24}$ This is

${ }^{23}$ On looting barbarians in the Northeast of Gaul in the middle of the fourth century and the consequences of their actions see 15.8.1; 15.8.19; 16.2.2; 16.2.5 ff.; $16.2 .9 \mathrm{ff}$.; 16.3-4; 16.5.14; 16.11.3 ff.; 17.3-6. On Aquitania as his supply base see Ammianus Marcellinus 17.8.1.

${ }^{24}$ P.P.M. Erdkamp, Hunger and the Sword. Warfare and Food Supply in Roman Republican Wars, 264-30 B.C. (Amsterdam 1998), 208-269. On p. 240 he observes: "The crucial point is that the catastrophies of war hit the rural population very unevenly. A part of the peasantry was pushed below the minimum requirement for subsistence. Confronted not only with empty stores, destroyed fields, and stolen livestock, but also with the continued threat of hostile armies, many of the peasants that 
what happened in some Danube provinces and the Agri Decumates, already under Marcus Aurelius and again in the decades from 250 to 284. Witschel, not a firm believer in the existence of the third century crisis, has to admit, on the basis of sound archaeological evidence, that in those times people must have left their homesteads in those regions. ${ }^{25}$ From 238 this may also have happened in some parts of the Balkans.

In war-ridden areas problems caused by prolonged warfare were aggravated by banditry. To give one example: after 180 Danubian regions and the area of the Upper Rhine were infested by roving bands of robbers, deserters and barbarians who had stayed behind after the Marcomannic Wars of Marcus Aurelius. Their leader, Maternus, even besieged the legio VIII Augusta in its camp at Strasbourg and then invaded and plundered Italy. ${ }^{26}$

Secondly, the plague. There is no certainty about the demographic consequences of the epidemics that raged over the empire from A.D. 166 and again in the decades from 250 to 280 . Some regions may have been afflicted more than other ones, but the overall effect must have been an - at least temporary - decline in population and tax-payers, in a period in which the costs of the military forces did not decrease, as Duncan-Jones demonstrates for the Antonine plague. ${ }^{27} \mathrm{~A}$ decrease in population in war-ridden areas, aggravated by the consequences of epidemics meant less production, smaller food surpluses, less tax income, a weakened logistical basis in the hinterland of important armies, and more pressure on the remaining farmers to hand over to the military an ever bigger percentage of their harvests. In such regions the decline in non-military population undoubtedly led to a more uneven distribution of people: relatively more soldiers, fewer farmers. Admittedly the military constituted at best only $1 \%$ of the population of the

were affected will have left their farms in search of more secure conditions of survival. Whether they stayed on the land depended on the seriousness of the problems they faced, but also on the alternative subsistence strategies to be found elsewhere and on the stake they had in their surroundings, in the form of ownership of land or livestock, and the social relations with kin and patrons".

${ }^{25}$ Witschel 1999, op.cit. (n. 9), 178 ff.; 207 ff. Cf. G. von Bülow, 'Zu den Verhältnissen in der Landwirtschaft: II 1, Die archăologischen Quellen zur Entwicklung der Villenwirtschaft', in Johne 1993, op.cit. (n. 4), 32-36.

${ }^{26}$ On Maternus and his army of bandits see Herodian 1.10; SHA, Commodus 16.2; Niger 3.4; AE 1956, 90. See F. Grosso, La lotta politica al tempo di Commodo (Turin 1964), 437 ff.; C.R. Whittaker, Herodian I (London/ Cambridge, MA, 1969), 62 f. n.1; G. Alföldy, 'Bellum desertorum', in Alföldy 1989, op.cit. (n.2), 69-80 (= Bonner Jahrbücher 171 [1971], 367-376).

${ }^{27}$ R.P. Duncan-Jones, 'The Impact of the Antonine Plague', Journal of Roman Archaeology 9 (1996), 108-136. On both periods of plague, about A.D. 166-190 and c. 250-280, see E. Lo Cascio, 'La dissoluzione dell' impero Romano d' Occidente: la spiegazione demografica', in G. Cacciatore, et al., eds., Filosofia e storia della cultura. Studi in onore di Fulvio Tessitore (Naples 1997), $168 \mathrm{ff}$. and Carrié \& Rousselle 1999, op.cit. (n.4), 521 ff. 
empire, but this problem did not affect the empire as a whole, but relatively thinly populated areas where a lot of soldiers were garrisoned and which had been infested by the cumulative effects of prolonged warfare, banditry and the plague. In such regions the second and particularly the third quarter of the third century were periods of crisis.

Thirdly, the decline of the epigraphical habit. Another phenomenon that has often been interpreted as a sign of a deeper crisis is the decrease in building activities, accompanied by a steep decline in the numbers of inscriptions, in many, if not practically all, cities of the empire. This decline set in under Severus Alexander, perhaps even earlier, and progressively continued during the next decades of the third century. ${ }^{28}$ This may be a sign of the tensions I mentioned above: local culture continuously lived on, but its most expensive aspects, like building, already stopped short. Local notables who progressively came under control of military foragers and curatores, and had to share their entitlement to local surpluses and facilities with them, undoubtedly lost status, started to consider euergesia an obligation more than a privilege, and had no longer sufficient means to pay for buildings, monuments, the upkeep of existing local infrastructures, games and other manifestations of public culture and religion. And why boasting about unavoidable, ruinous obligations, in inscriptions on monuments, in times during which local notables were no longer masters in their own communities?

A fourth symptom of a deeper, more complex crisis is the debasement of the imperial coinage, accompanied by the disappearance of all other kinds of coinage from 260. As Harl, Bland and Carrie have splendidly summarised, the debasement of the imperial coinage set in under Commodus and the Severi and speeded up from 238, particularly from 249 . The antoninianus went down from $47.7 \%$ silver in the years $238-244$ to $40.24 \%$ under Philip the Arabian and Decius, to $21.86 \%$ in the years 253-255, to an average of $11,44 \%$ in 260 to 263 , and to $2.7 \%$ under Claudius II, to recover a little bit in the period 274-282. The production of denarii slowed down from 240 and stopped after 250. Weights and qualities of gold coins, the aurei, were also reduced. Roger Bland demonstrates that by 253 aurei generally weighed less than a third of what they had done in 193. By the middle of the third century gold pieces were no longer issued to a consistent standard and shortly after 253 the mint of Rome was to debase the gold coinage for the first time in

\footnotetext{
${ }^{28}$ See R. MacMullen, 'The Epigraphical Habit in the Roman Empire', American Journal of Philology 103 (1982), 233-246.
} 
Roman imperial history. Aurei ceased to be proper coins. Increasingly the gold coins that have come down to us today from those times are either pierced or mounted in jewellery. The gold coinage of Severus Alexander set in a trend which is very significant in this respect, which is that the range of weights of individual aurei widens greatly. The overall mean weight remains the same as it had done for Elagabalus $(6.49 \mathrm{~g})$, but the coefficient of deviation is now twice as high. Having become individual lumps of gold, in the third quarter of the third century aurei no longer constituted a coin denomination. ${ }^{29}$

The debasement of the coinage may have been caused by a lack of plate, decreasing tax returns and - particularly from 253 - the decentralisation of coin production.

Debasement of the coinage should have been followed by a rise in prices. An awkward problem is, however, that there are no traces of an immediately ensuing running inflation. On the basis of mainly papyrological evidence Lo Cascio argues that there was no direct connection between the debasement of the coinage and a rise of the prices. He maintains that average nominal prices ("prezzi in unità di conto") did not rise to about $270 .{ }^{30}$ Real prices in war-stricken areas, however, must have fluctuated heavily, and were undoubtedly often very high indeed. Besides Egypt had an economic life of its own, and had until 260 its own coinage, which more or less kept its intrinsic value. In other parts of the empire, particularly in war-ridden areas, inflation may have come earlier. World - prices or empire - wide prices did not exist. Prices of grain and other commodities could differ from one valley or island to another. Like prices, coin - circulation was a regional matter, as Duncan - Jones has convincingly argued. ${ }^{31}$ Admittedly soldiers took coins from one region to another and mints were sometimes transferred to other places, particularly in the second half of the third century, but apparently those phenomena did not disturb regional coin-circulation permanently.

\footnotetext{
${ }^{29}$ On the debasement of the coinage in the third century A.D. see Carson 1990, op.cit. (n.6), $61 \mathrm{ff}$; R.F. Bland, The Development of Gold and Silver Coin Denominations, A.D. 193-253, in C.E. King \& D.G. Wigg, Coin Finds and Coin Use in the Roman World. The Thirteenth Oxford Symposium on Coinage and Monetary History, 25.-27.3.1993 (Berlin 1996), 63-100; K.W. Harl, Coinage in the Roman Economy, 300 B.C. to A.D. 700 (Baltimore/ London 1996), 126-148; Carrié \& Rousselle 1999, op.cit. (n.4), 127 ff.; L. de Blois, 'Monetary Policies, the Soldiers' Pay, and the Onset of Crisis in the First Half of the Third Century A.D.', in P.P.M. Erdkamp, ed., The Roman Army and the Economy (Amsterdam 2002), 90-107.

${ }^{30}$ E. Lo Cascio, 'Prezzi in oro e prezzi in unità di conto tra il III e il IV secolo d.C.', in J. Andreau, et al., eds., Prix et formation des prix dans les économies antiques. Entretiens d' archéologie et d' histoire (Saint Bertrand de Comminges 1997), 161-182, esp. 164.

${ }^{31}$ R.P. Duncan-Jones, Money and Government in the Roman Empire (Cambridge 1994).
} 
Nominal, official prices, which the imperial government paid to farmers and landed proprietors who delivered supplies to the armies and the provincial governors, may have been kept stable in an artificial way. On the basis of some evidence and a lot of good reasoning Michel Christol thinks that Roman commanders used debased coins to pay for food, goods and transport facilities ${ }^{32}$, like frumentum emptum. If he is right, the victims of the debasement of the coinage were not the soldiers, who received lots of bad coins instead of a few good denarii, and were compensated by donatives and gifts in kind, but landed proprietors and farmers, who saw the coins they received deteriorate fast, without any adjustment of the official prices for the food and goods they had to deliver. On regional and local markets, however, prices may have gone up rapidly. They could not profit by this rise in prices, because their surplus was taken away from them by the military and other Roman officials, many of whom must have become rich, like Valens in 69, by taking more than their due, paying with debased coins, and selling their own part of the booty at much higher prices on market-places. Added to other problems which existed in war-ridden areas, this must have brought many farmers and local landed proprietors on the verge of ruin. Again, in such areas and the further hinterlands of big armies, there was a crisis indeed in the third century, especially in the period 249-284.

In conclusion: the crisis of the third century in the Roman empire was harsh reality indeed in war-ridden areas and the adjacent hinterlands, especially in the period 249-284. In these territories a deep, many-sided crisis threatened traditional structures and started to bring about profound changes. In other regions there was continuity of existing social, economic, cultural, and religious structures, but in an ever more tense situation in which local elites could not make ends meet and had to give up building activities and the concomitant epigraphic habit. Everywhere the status of local notables declined, to the advantage of military foragers and controlling bureaucrats and curatores.

Nijmegen, The Netherlands, November 2001.

${ }^{32}$ A good summary of Christol's theory is given by Carrié \& Rousselle 1999, op.cit. (n.4), 130. 